\title{
Karakteristik Massa Katup Limbah dan Tinggi Angkat Terhadap Efisiensi Pompa Hidram 3 Inci
}

\author{
${ }^{1}$ Muhamad Jafri, ${ }^{2}$ Nurhayati, ${ }^{3}$ Dominggus G. H. Adoe, ${ }^{4}$ Gusnawati \\ 1,2,3,4 Prodi Teknik Mesin Universitas Nusa Cendana, Jl. Adisucipto-Penfu-Kupang-NTT, Indonesia \\ e-mail: muhamad jafri@staf.undana.ac.id
}

\begin{abstract}
Abstrak
Tujuan penelitian adalah untuk menganalisis pengaruh massa katup limbah dan tinggi angkat terhadap efisiensi pompa hidram. Metode yang digunakan adalah eksperimen terhadap spesimen, dan dianalisis menggunakan persamaan matematis dalam teori pompa hidram. Data-data yang diukur adalah debit air masuk, debit air limbah, dan debit air keluar. Variabel bebas dalam penelitian ini adalah massa katup limbah yaitu $1.5 \mathrm{~kg}, 2.0 \mathrm{~kg}, 2.5 \mathrm{~kg}, 3.0 \mathrm{~kg}$ dan tinggi angkat yaitu $3 \mathrm{~m}, 5 \mathrm{~m}, 7 \mathrm{~m}$. Selanjutnya analisis head loss dan efisiensi pompa hidram. Hasil penelitian menunjukan bahwa massa katup limbah dan tinggi angkat berpengaruh terhadap efisiensi pompa hidram. Efisiensi pompa hidram tertinggi dalam penelitian ini adalah pada tinggi angkat $5 \mathrm{~m}$ dan massa katup limbah $1.5 \mathrm{~kg}$ sebesar $60.60 \%$. Sedangkan efisiensi pompa hidram terendah terjadi pada tinggi angkat $7 \mathrm{~m}$ dan massa katup limbah $3.0 \mathrm{~kg}$ sebesar $27.10 \%$.
\end{abstract}

Kata kunci: Massa katup limbah; Tinggi angkat; Efisiensi pompa hidram

\begin{abstract}
The research aim was to analyze the effect of the wastevalve mass and the deliver head on the hydram pump efficiency. The method used is the experimental method for the 3-inch hydram pump specimen, then analyzed using mathematical equations in the theory of the hydram pump on the head loss and pump efficiency. The data measured are the inflow, wastewater, and hydram pump outflow. The independent variables in this study were the wastevalve mass, namely $1.5 \mathrm{~kg}, 2.0 \mathrm{~kg}, 2.5 \mathrm{~kg}$, and $3.0 \mathrm{~kg}$, and deliver head, namely $3 \mathrm{~m}, 5 \mathrm{~m}$, and $7 \mathrm{~m}$. The results showed that the wastevalve mass and deliver head an effect on the hydram pump efficiency. The highest efficiency of the hydram pump is at a deliver head of $5 \mathrm{~m}$ with $1.5 \mathrm{~kg}$ of wastevalve mass, which is $60.60 \%$. Meanwhile, the lowest hydram pump efficiency occurs at a deliver head of $7 \mathrm{~m}$ with $3.0 \mathrm{~kg}$ of wastevalve mass, which is $27.10 \%$.
\end{abstract}

Keywords: Wastevalve mass; Deliver head; Hydram Pump Efficiency

\section{Pendahuluan}

Pompa adalah salah satu alat yang memberikan energi untuk menaikkan, memindahkan, atau mengkompresi cairan. Pompa sentrifugal sejauh ini merupakan jenis pompa yang paling umum digunakan (Jafri et al., 2020). Pompa yang umumnya digunakan adalah dengan penggerak listrik ataupun diesel. Namun banyak daerah di Indonesia khususnya di daerah terpencil, tidak memiliki akses listrik untuk mengoperasikan pompa (Jafri et al, 2016; Jafri et al, 2019). Salah satu solusinya adalah membuat sebuah teknologi pompa yang tidak menggunakan tenaga diesel ataupun tenaga listrik yaitu pompa hidram. 
Pompa hidram atau singkatan dari hidrolik ram berasal dari kata hidro yang berarti air (cairan), ram yang berarti hantaman, pukulan atau tekanan (Kahar, 2017). Penggunaan pompa hidram memiliki banyak keuntungan dibandingkan penggunaan jenis pompa lain yaitu tidak membutuhkan bahan bakar minyak (bensin atau solar), bentuknya sederhana, cara pemeliharaannya mudah, pembuatannya tidak membutuhkan keterampilan khusus serta dapat bekerja 24 jam per hari.

Kapasitas pemompaan ram hidrolik tergantung pada ukuran dan aliran air pasokan serta pengiriman tinggi. Biasanya, sekitar sepuluh persen dari air penggerak dipompa ke atas, menurun seiring dengan bertambahnya ketinggian pengiriman. Seperti kebanyakan air tidak dipompa (dan bisa dikatakan terbuang percuma), sistem tidak memadai dalam kondisi dimana air langka (Inthachot et al., 2015). Sejak 1980-an kontribusi penelitian telah diusulkan untuk mengoptimalkan efisiensinya melalui beberapa modifikasi (Hussin et al., 2017).

Pompa hidram atau ram hidrolik adalah pompa yang menggunakan energi dari jumlah yang terus turun air untuk memompa sebagian ke ketinggian yang jauh lebih tinggi daripada tingkat semula di sumbernya. Tidak ada energi eksternal lain yang diminta selama persediaan air tersedia secara konstan, pompa akan tetap bekerja secara terus menerus dan otomatis (Harith et al., 2017). Komponen dari pompa ram hidrolik adalah tangki pemasok air, pipa penggerak, badan pompa, katup limbah, katup pengiriman, katup snifter, ruang udara, dan pipa pengiriman (Diwan et al., 2016) seperti pada gambar 1 .

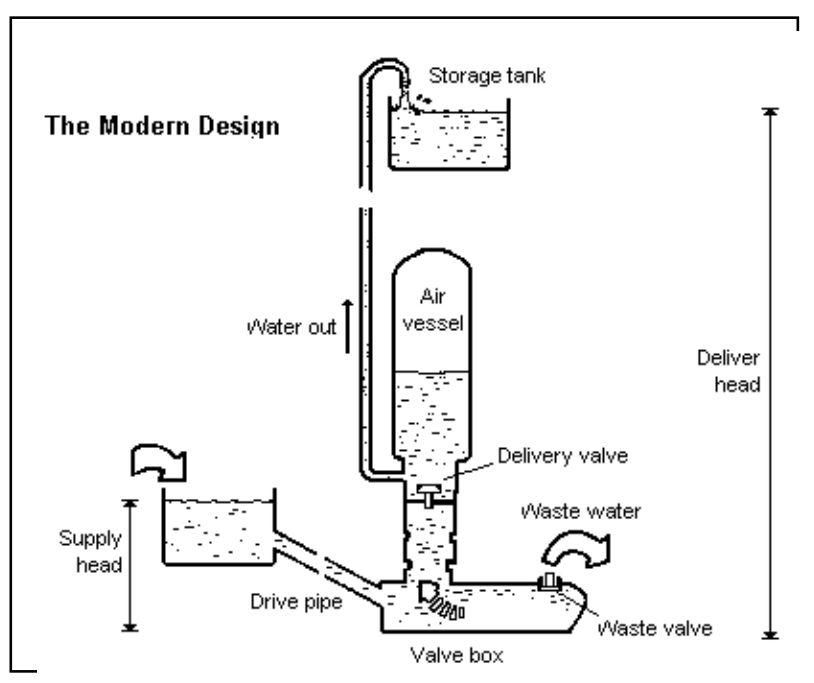

Gambar 1. Diagram of modern pump (Rohan et al., 2015).

Urutan proses pompa ram hidrolik terputus-putus karena perilaku membuka dan menutup limbah dan katup pengiriman. Perilaku pompa ram hidrolik bergantung pada fenomena water hammer yang diwakili pada saat penutupan dan pembukaan katup 
limbah dan pengiriman. Prosesnya dimulai saat air yang masuk ke pipa penggerak berasal dari tertentu ketinggian ketinggian dengan tekanan tinggi. Oleh karena itu, katup limbah ditutup oleh momentum air (Seth, J., 2013). Dengan demikian, tekanan tinggi tercipta yang akan menyebabkan katup pengiriman terbuka sehingga air bertekanan naik di ruang udara vakum. Karena itu, ruang udara akan menekan air yang menyebabkan katup pengiriman menutup dan katup udara akan terbuka sehingga air naik melalui pengiriman pipa mencapai tempat yang diinginkan (Young, 1996).

Pompa ram hidrolik adalah unit sederhana secara struktural yang terdiri dari dua bagian yang bergerak. Ini adalah katup impuls (atau limbah katup) dan pengiriman (periksa) katup. Unit ini juga terdiri dari ruang udara dan katup udara (Diwan et al., 2016). Tujuan yang ingin dicapai adalah untuk mengetahuai peningkatan efisiensi pompa hidram 3 inci dengan analisis pengaruh massa katup limbah dan tinggi angkat.

\section{Metode}

Alat yang digunakan dalam penelitian ini adalah pompa hidram 3 inci sebagai media uji, flow meter untuk mengukur debit air masuk $\left(Q_{\text {masuk }}\right)$, debit limbah ( $\left.Q_{\text {limbah }}\right)$ serta debit keluar (Qkeluar), stop watch untuk mengukur lamanya pengambilan data setiap sampel, kunci pipa untuk membuka dan mengunci sambungan pipa, Global Position Sistem (GPS) untuk mengukur variasi tinggi angkat. Sedangkan bahan-bahan yang digunakan dalam penelitian ini sebagian besar adalah pipa dan sambunga yaitu; pipa 3 inci, pipa 1 inci, sambungan pipa, sealtipe, dan air.

Variabel tetap dalam penelitian ini adalah pompa hidram ukuran 3 inci, diameter pipa masuk 3 inci, tinggi jatuh $1 \mathrm{~m}$, panjang langkah $3 \mathrm{~cm}$, diameter dalam katup limbah 2,25 inci, volume tabung 10 liter, diameter katup pengantar 2,5 inci, dan diameter pipa keluar 1 inci. Variabel bebas dalam penelitian ini adalah massa katup limbah yaitu $1.5 \mathrm{~kg}, 2.0 \mathrm{~kg}, 2.5 \mathrm{~kg}, 3.0 \mathrm{~kg}$ dan tinggi angkap pemompaan yaitu $3 \mathrm{~m}, 5$ $\mathrm{m}$, dan $7 \mathrm{~m}$. Sedangkan variabel terikatnya adalah debit dan efisiensi pompa hidram.

Langkah-langkah pengujian yang diterapkan dalam penelitian ini diuraikan sebagai berikut:

a. Melakukan instalasi pompa hidram 3 inci, yang dimulai dari memasang reservoir penampung, pompa pengisi reservoir pengarah, reservoir pengarah, pipa isap, alat ukur flow meter, pompa hidram 3 inci, bak limbah, alat ukur debit aliran pada katup limbah, pipa pengantar 1 inci, alat ukur debit aliran keluar.

b. Pada pengujian pertama, sampel dari dua variable bebas yang dipasang adalah tinggi angkat 7 meter dan massa katup limbah 1.5 inci. 
c. Menjalankan pompa dengan cara membuka stop kran pada pipa isap, dan sacara bersamaan pompa reservoir pengarah dihidupkan untuk menjaga level air dalam reservoir pengarah.

d. Pada saat pompa berjalan normal dilakukan pencatatan debit aliran air pada

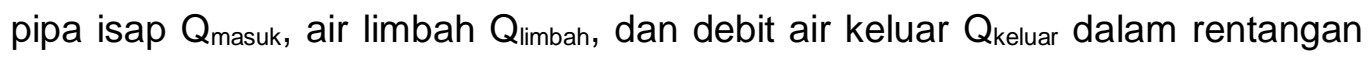
waktu 30 detik secara bersamaan.

e. Setelah mencatat ketiga data debit aliran, pompa dimatikan dengan cara menutup stop caran pada pipa isap.

f. Menset ulang pompa yaitu massa katup limbah $1.5 \mathrm{~kg}$ diganti dengan mass katup limbah $2.0 \mathrm{~kg}$ untuk tinggi angkat yang sama.

g. Mengulangi langkah c sampai langkah e, dan seterusnya sampai massa katup limbah $3.0 \mathrm{~kg}$.

h. Mengulang langkah b samapi langkah g untuk tinggi angkat $5 \mathrm{~m}$ dan $3 \mathrm{~m}$.

\section{Analisis Data}

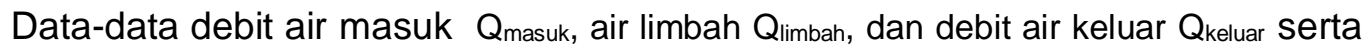
data variabel tetap digunakan untuk menganalisa head pompa. Analisis head pompa terbagi 2 yaitu analisis head loss mayor dan head loss minor. Persamaan yang digunakan untuk head loss mayor adalah;

$$
H_{f}=f \cdot \frac{L}{D} \cdot \frac{v^{2}}{2 g}
$$

Di mana:

$$
\begin{aligned}
H_{f} & =\text { head loss karena gesekan }(\mathrm{m}) \\
f & =\text { faktor gesekan } \\
g & =\text { percepatan gravitasi }\left(9,81 \mathrm{~m} / \mathrm{s}^{2}\right) \\
L & =\text { panjang pipa }(\mathrm{m}) \\
D & =\text { diameter pipa }(\mathrm{m}) \\
V & =\text { kecepatan rata-rata aliran dalam pipa }(\mathrm{m} / \mathrm{s})
\end{aligned}
$$

Sedangakan persamaan untuk head loss minor adalah;

$$
H_{i}=K_{i} \frac{v^{2}}{2 g}
$$

Di mana:

$$
\begin{aligned}
& H_{i}=\text { head loss karena bentuk ujung masuk pipa }(\mathrm{m}) \\
& K_{i}=\text { koefisien head loss karena bentuk ujung masuk } \\
& v=\text { kecepatan rata-rata aliran dalam pipa }(\mathrm{m} / \mathrm{s})
\end{aligned}
$$


Selanjutnya adalah analisis efisiensi pompa. Data yang digunakan dalam analisis pompa adalah data debit air masuk Qmasuk, air limbah Qlimbah, dan debit air keluar Qkeluar serta data hasil analisis head loss. Persamaan yang digunakan untuk efisiensi pompa adalah persamaan D'Aubuisson :

$$
\eta_{D}=\frac{\left(Q_{\text {keluar }}\right)\left(H_{\text {efkeluar }}\right)}{\left(Q_{\text {keluar }}+Q_{\text {limbah }}\right) H_{\text {efmasuk }}} \times 100 \%
$$

dimana :

$$
\begin{aligned}
& \eta_{D}: \text { Efisiensi pompa hidram (\%) } \\
& Q_{\text {keluar: }} \text { Debit air hasil pemompaan }\left(\mathrm{m}^{3} / \mathrm{s}\right) \\
& Q_{\text {limbah }} \text { : Debit air yang keluar dari katup limbah }\left(\mathrm{m}^{3} / \mathrm{s}\right) \\
& \mathrm{H}_{\text {ef,masuk }} \text { : Head efektif masuk }(\mathrm{m}) \\
& \mathrm{h}_{\text {ef,keluar }} \text { : Head efektif keluar }(\mathrm{m})
\end{aligned}
$$

\section{Hasil dan Pembahasan}

\begin{tabular}{|c|c|c|c|c|c|}
\hline No & $\begin{array}{c}\text { Tinggi Angkat, } \\
\text { hd }(\mathrm{m})\end{array}$ & $\begin{array}{c}\text { Massa Katub } \\
\text { Limbah (kg) }\end{array}$ & $\begin{array}{c}\text { Debit Aliran } \\
\text { Masuk, } \\
\text { Qmasuk (L/s) }^{\text {Mmos }}\end{array}$ & $\begin{array}{l}\text { Debit Aliran } \\
\text { Limbah, } \\
\text { Qlimbah (L/s) }\end{array}$ & $\begin{array}{c}\text { Debit Aliran } \\
\text { Keluar, } \\
\text { Qkeluar (L/s) }\end{array}$ \\
\hline 1 & 3 & 1.5 & 1.209777778 & 1.040000000 & 0.169777778 \\
\hline 2 & 3 & 2.0 & 1.480666667 & 1.341111111 & 0.139555556 \\
\hline 3 & 3 & 2.5 & 1.594444444 & 1.436666667 & 0.157777778 \\
\hline 4 & 3 & & 1.769555556 & 1.611111111 & 0.158444444 \\
\hline 5 & 5 & 1.5 & 1.221111111 & 1.073333333 & 0.147777778 \\
\hline 6 & 5 & 2.0 & 1.507777778 & 1.348888889 & 0.158888889 \\
\hline 7 & 5 & 2.5 & 1.605000000 & 1.466111111 & 0.138888889 \\
\hline 8 & 5 & 3.0 & 1.691666667 & 1.581111111 & 0.110555556 \\
\hline 9 & 7 & 1.5 & 1.386666667 & 1.272777778 & 0.113888889 \\
\hline 10 & 7 & 2.0 & 1.447555556 & 1.337222222 & 0.110333333 \\
\hline 11 & 7 & 2.5 & 1.662111111 & 1.571666667 & 0.090444444 \\
\hline 12 & 7 & 3.0 & 1.745777778 & 1.672222222 & 0.073555556 \\
\hline
\end{tabular}

Hasil

Data-data hasil pengujian; debit air masuk $Q_{\text {masuk, }}$ debit air katup limbah $Q_{\text {limbah, }}$ maupun debit air keluar $\left(Q_{\text {keluar }}\right)$ dapat dilihat pada tabel 1.

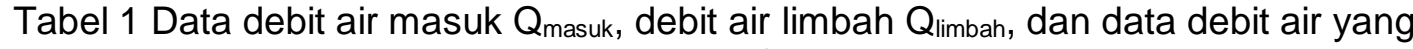
dihasilkan (Qkeluar).

Data pada Tabel 1 dapat dibuat dalam bentuk grafik seperti pada gambar 2 dan gambar 3. 


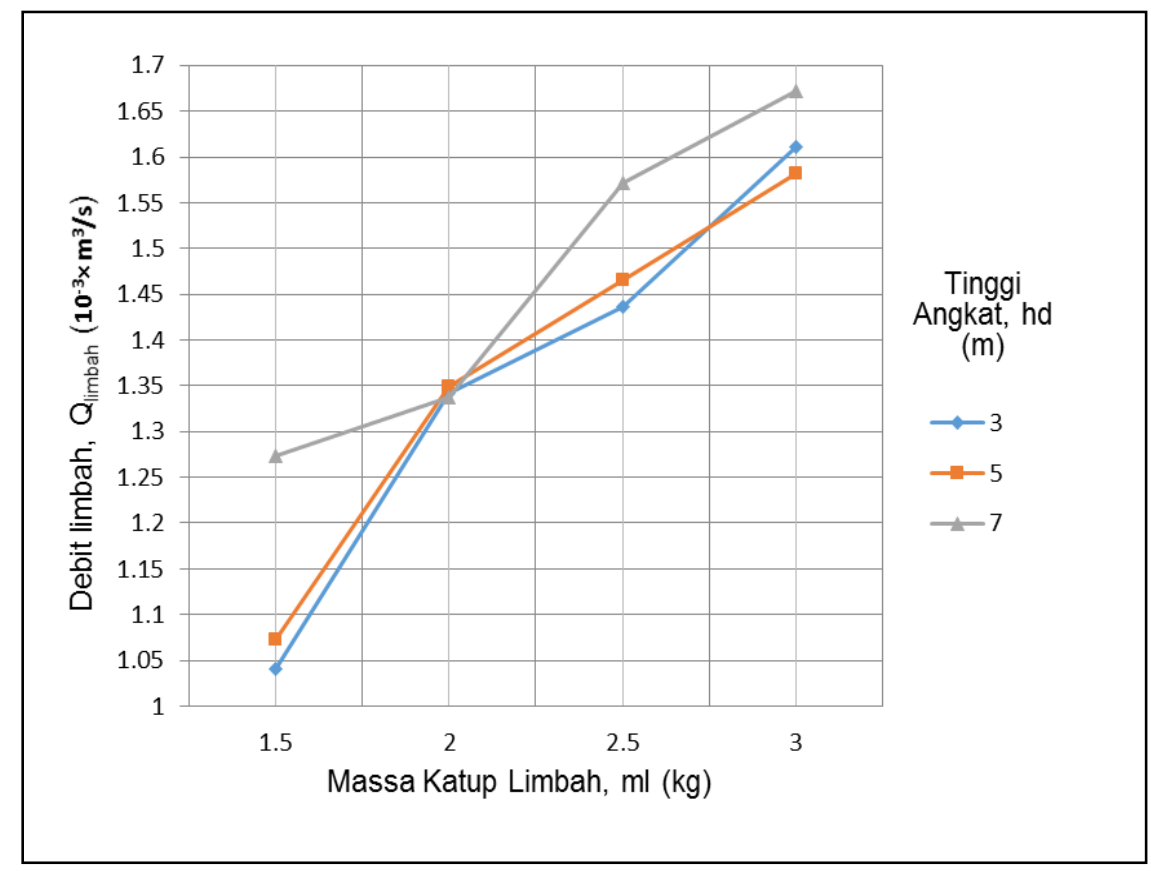

Gambar 2. Grafik hubungan antara massa katup limbah dan debit aliran dalam katup limbah untuk setiap tinggi angkat.

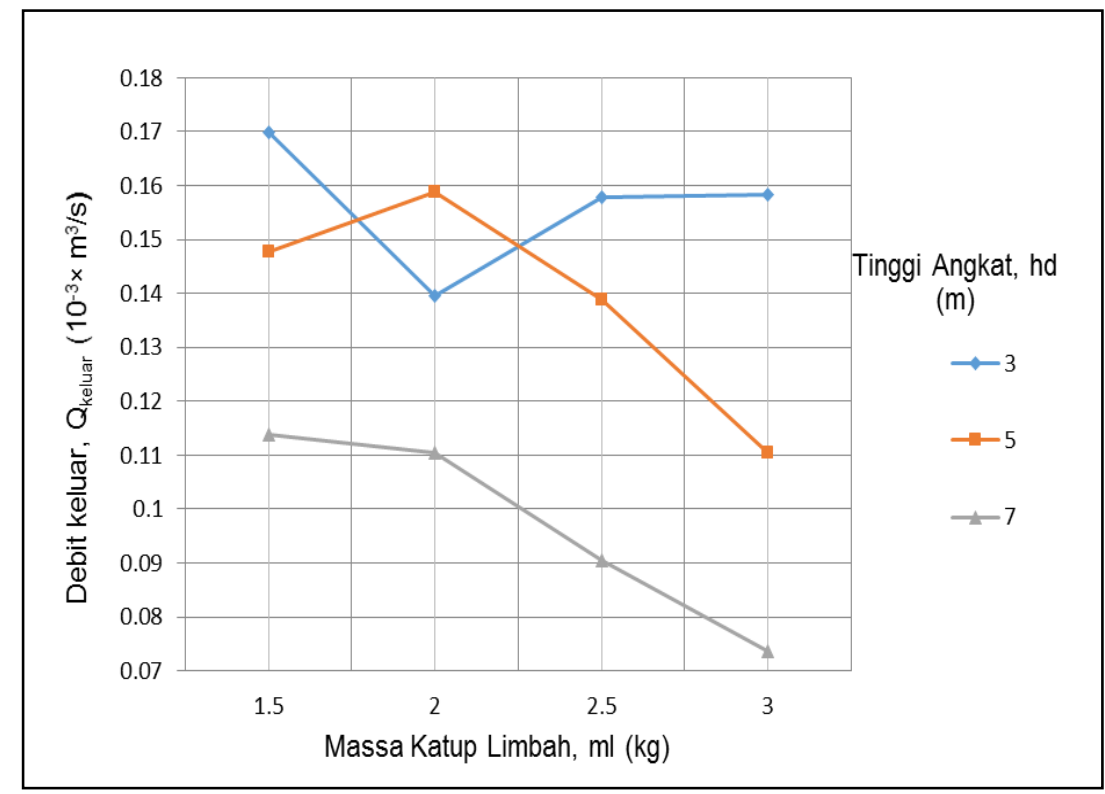

Gambar 3. Grafik hubungan antara debit aliran dalam saluran keluar dan massa katup limbah untuk setiap tinggi angkat.

Data hasil penelitian pada tabel 1 dianalisis untuk mengetahui head efektif masuk ( $\left.H_{\text {ef, masuk }}\right)$, head efektif keluar ( $H_{\text {ef, keluar }}$ ), dan efisiensi D'Aubuisson pompa. Hasil analisisnya bisa ditunjukkan pada tabel 2. 
Tabel 2 Hasil analisi data untuk head efektif masuk ( $\left.H_{\text {ef, masuk }}\right)$, head efektif keluar $\left(\mathrm{H}_{\mathrm{ef}, \mathrm{keluar}}\right)$, dan efisiensi D'Aubuisson pompa.

\begin{tabular}{|c|c|c|c|c|c|c|c|}
\hline \multirow{2}{*}{ No } & \multirow{2}{*}{$\begin{array}{l}\text { hd } \\
\text { (m) }\end{array}$} & \multirow{2}{*}{$\begin{array}{l}\mathrm{Mw} \\
(\mathrm{kg})\end{array}$} & \multicolumn{2}{|c|}{ Debit Aliran, $\mathrm{Q}\left(\mathrm{m}^{3} / \mathrm{s}\right)$} & \multirow{2}{*}{$\begin{array}{c}\mathrm{H}_{\text {ef,masuk }} \\
(\mathrm{m})\end{array}$} & \multirow{2}{*}{$\begin{array}{c}\mathrm{H}_{\text {ef,keluar }} \\
(\mathrm{m})\end{array}$} & \multirow{2}{*}{$\begin{array}{c}\text { Efisiensi } \\
\text { D'Aubisson (\%) }\end{array}$} \\
\hline & & & $Q_{\text {limbah }}$ & $Q_{\text {keluar }}$ & & & \\
\hline 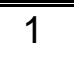 & 3 & 1.5 & 0.001040 & 0.000169778 & 0.983559 & 6.885463 & 98.24 \\
\hline 2 & 3 & 2.0 & 0.001341 & 0.000139556 & 0.975372 & 6.922611 & 66.89 \\
\hline 3 & 3 & 2.5 & 0.001436 & 0.000157778 & 0.971442 & 6.901082 & 70.30 \\
\hline 4 & 3 & 3.0 & 0.001611 & 0.000158444 & 0.964824 & 6.900244 & 64.04 \\
\hline 5 & 5 & 1.5 & 0.001073 & 0.000147778 & 0.983249 & 4.913223 & 60.47 \\
\hline 6 & 5 & 2.0 & 0.001349 & 0.000158889 & 0.974461 & 4.899684 & 52.99 \\
\hline 7 & 5 & 2.5 & 0.001466 & 0.000138889 & 0.971062 & 4.923348 & 43.87 \\
\hline 8 & 5 & 3.0 & 0.001581 & 0.000110556 & 0.967852 & 4.951432 & 33.43 \\
\hline 9 & 7 & 1.5 & 0.001273 & 0.000113889 & 0.978399 & 2.948459 & 24.75 \\
\hline 10 & 7 & 2.0 & 0.001337 & 0.000110333 & 0.976461 & 2.951628 & 23.04 \\
\hline 11 & 7 & 2.5 & 0.001572 & 0.000090444 & 0.968966 & 2.967495 & 16.66 \\
\hline 12 & 7 & 3.0 & 0.001672 & 0.000073556 & 0.965763 & 2.978501 & 12.99 \\
\hline
\end{tabular}

\section{Pembahasan}

Untuk memudahkan dalam membahas hasil analisis data, tabel 2 dibuat dalam bentuk grafik hubungan antara variabel bebas dan variabel tetap seperti yang ditunjukkan pada gambar 4 .

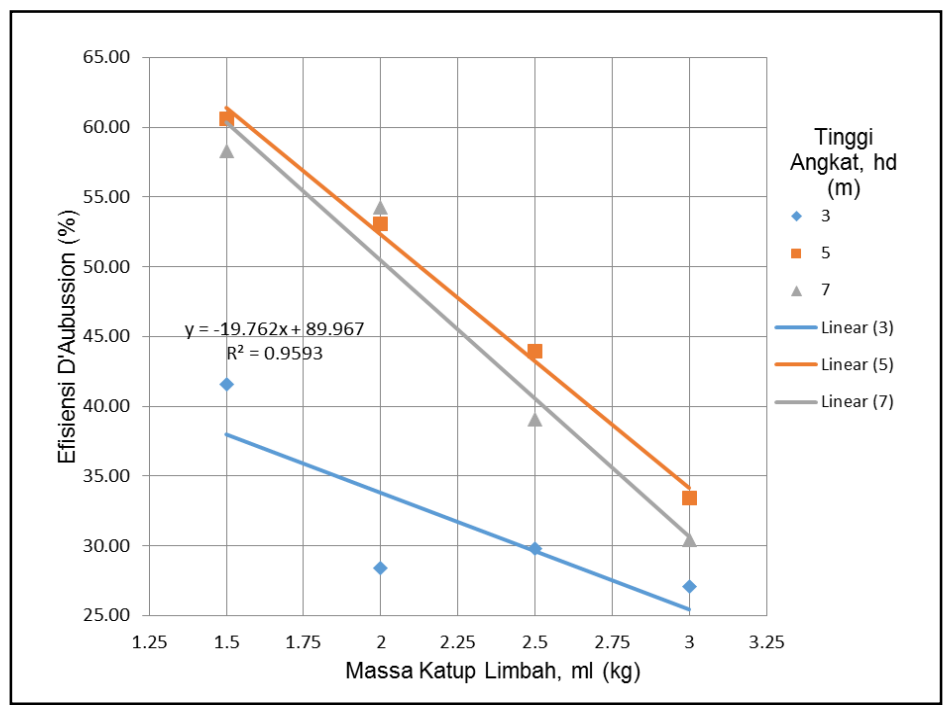

Gambar 4. Grafik hubungan antara massa katup limbah dan efisiensi pompa hidram untuk setiap variasi tinggi angkat.

Grafik pada gambar 4 menunjukkan bahwa, efisiensi pompa hidram tertinggi terjadi pada massa katup limbah $1.5 \mathrm{~kg}$ yaitu sebesar $60.60 \%$, dan efisiensi terendah terjadi pada massa katup $3 \mathrm{~kg}$ yaitu $27.10 \%$. Hasil penelitian ini menunjukkan bahwa 
massa katup limbah berpengaruh terhadap efisiensi pompa hidram. Sejalan dengan hasil percobaan dan analisa varians serta regresi response surface, bahwa faktor volume tabung udara dan beban katup limbah berpengaruh pada efisiensi pompa (San dan Santoso, 2003). Semakin besar massa katup limbah semakin kecil efisiensi pompa hidram. Hasil yang sama ditujukan pada penelitian Cahyanta dan Taufik (2008), dengan variasi massa 410 g, 450 g, 490 g, 540 g, 580g dan 630 g. Di mana kapasitas pemompaan, head hantar dan efisiensi yang dihasilkan pompa berbanding terbalik dengan variasi beban katup limbah yang digunakan. Efisiensi tertinggi terjadi pada massa katup limbah $410 \mathrm{~g}$. Penelitian lain menunjukkan bahwa efisiensi pompa hidram dipengaruhi oleh volume tabung udara dan berat beban katup buang yaitu efisiensi semakin kecil jika volume tabung udara dan berat beban katup limbah ditambah (Sulistiawan, Wahyudi, Pradana, dan Fuhaid, 2013).

Massa katup limbah dipengaruhi oleh head suplai atau momentum aliran air untuk menggerakkan pompa. Head suplai air yang lebih tinggi mengakibatkan diperlukan gaya gravitasi katup yang lebih besar untuk mengkompensasi gaya impuls yang bekerja pada cakram katup. Jika massa katup terlalu ringan, katup limbah tetap dalam posisi tertutup dan tidak dapat dibuka secara otomatis oleh berat gravitasinya. Sebaliknya jika massa katup limbah terlalu besar, maka katup limbah akan tetap terbuka.

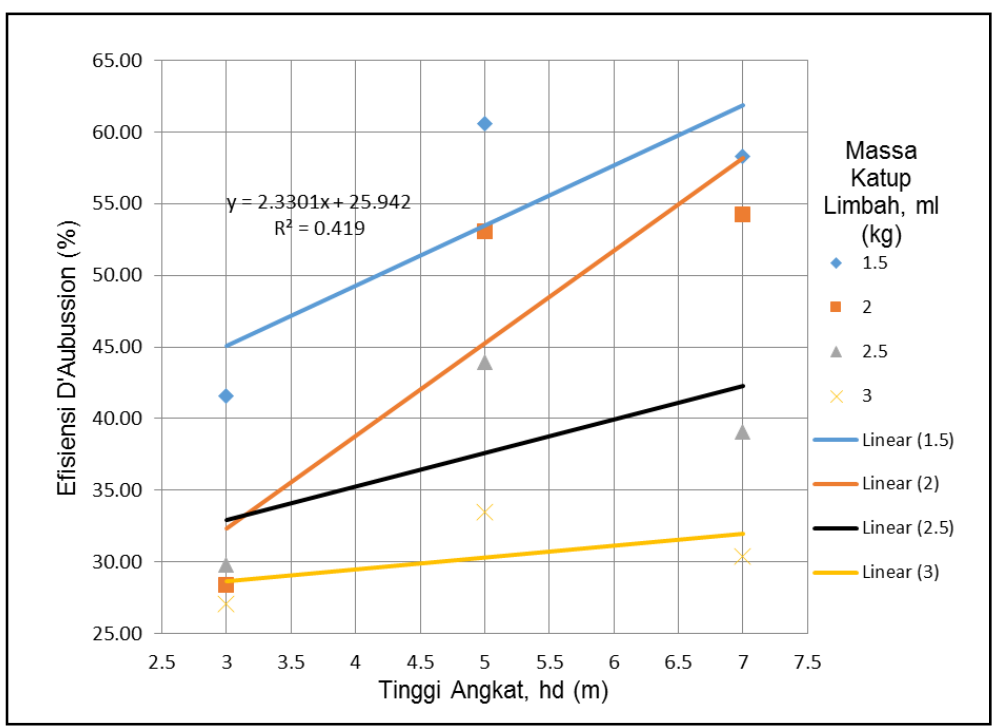

Gambar 5. Grafik hubungan antara tinggi angkat dan efisiensi pompa hidram untuk setiap variasi massa katup limbah.

Grafik pada gambar 5 menunjukkan bahwa, efisiensi pompa hidram tertinggi terjadi pada tinggi angkat $5 \mathrm{~m}$ yaitu sebesar $60.60 \%$, dan efisiensi terendah terjadi pada tinggi angkat $3 \mathrm{~m}$ yaitu $27.10 \%$. Namun secara keseluran menunujukkan bahwa 
untuk setiap kenaikan tinggi angkat, terjadi kenaikan efisiensi. Tentunya hasil ini berbanding terbalik dengan debit air pada saluran keluar yang meunjukkan bahwa semakin besar tinggi angkat, semakin kecil debit air pada saluran keluar. Kita ketahui bahwa, berdasarkan persamaan efisiensi pompa hidram, efisiensi ini secara langsung dipengaruhi oleh debit air yang dihasilkan, debit air melalui katup limbah, head sisi masukkan dan head sisi keluaran. Antara efisiensi dan debit air pada saluran keluar memiliki hubungan berbanding lurus. Namun dalam hasil menunjukkan lain. Hal disebabkan oleh head keluaran sebagai pengali dari persamaan efisiensi, dinaikkan secara signifikan, sementara debit air yang keluar untuk setiap variabel, tidak segnifikan.

\section{Kesimpulan}

Berdasarkan hasil penelitian dan analisis data dapat disimpulkan bahwa efisiensi tertinggi untuk variasi massa katup limbah adalah pada massa $1.5 \mathrm{~kg}$ yaitu sebesar $60.60 \%$ dan efisiensi terendah pada variasi massa $3.0 \mathrm{~kg}$ yaitu sebesar 27.10 $\%$. Sedangkan untuk Variasi tinggi angkat, efisiensi tertinggi diperoleh pada tinggi angkat $5 \mathrm{~m}$ sebesar $60.60 \%$ dan variasi tinggi angkat $7 \mathrm{~m}$ diperoleh efisiensi terendah sebesar $27.10 \%$.

\section{Daftar Pustaka}

Cahyanta, Y.A., dan Taufik, I. (2008). Studi terhadap prestasi Pompa Hidraulik Ram dengan variasi beban katup limbah, Jurnal IImiah Teknik Mesin CAKRAM, 2(2), 92-96.

Diwan, P., Patel, A., and Sahu, L. (2016). Design and fabrication of Hydraulic Ram with methods of improving efficiency. International Journal of Current Engineering and Scientific Research (IJCESR), 3(4), 5-13.

Hanafie, J., dan de Longh, H. (1979). Teknologi pompa Hydraolik Ram: Buku petunjuk untuk pembuatan dan pemasangan. Bandung: PTP-ITB Ganesha.

Harith, M. N., Bakar, R. A., Ramasamy, D., dan Ma Quanjin. (2017). A significant effect on $f$ low analysis \& simulation study of improve design hydraulic pump. 4th International Conference on Mechanical Engineering Research (ICMER2017), IOP Conference Series: Materials Science and Engineering.

Hussin, N.S.M., Gamil, S.A., Amin, N.A.M., Safar, M.J.A., Majid, M.S.A., Kazim, M.N.F.M., dan Nasir, N.F.M. (2017). Design and analysis of hydraulic ram water pumping system. In Proceedings of the International Conference on Applications and Design in Mechanical Engineering (ICADME 2017), Penang, Malaysia, 21-22 August 2017. 
Inthachot, M. et al. (2015) Hydraulic ram pumps for irrigation. In Northern Thailand Agriculture and Agricultural Science Procedia 5, 107-114.

Jafri, M., Bale, J.S., and Thei, A.R. (2020). Experimental study of waste valves and delivery valves diameter effect on the efficiency of 3-inch Hydraulic Ram Pumps. International Journal of Fluid Machinery and Systems (IJFMS), 13(3), DOI: http://dx.doi.org/10.5293/ IJFMS.2020.13.3.615.

Jafri, M., dan Sanusi, A. (2019). Analysis effect of supply head and delivery pipe length toward the efficiency Hydraulic Ram 3 inches. International Research Journal of Advanced Engineering and Science, 4(2), 263-266, DOI: 10.5281/zenodo.3153468.

Jafri, M., Gusnawati, dan Banamtuan, A. (2016). Analisa beda tinggi katup dan variasi diameter pipa inlet terhadap unjuk kerja Pompa Hidram ukuran 2 inchi. LJTMU, 3(1), 71-76.

Kahar, K. (2017). Pengaruh jumlah katup hisap dan katup buang terhadap kinerja Pompa Hidram, Jurnal Pertanian Terpadu, 2, 92-103.

Rohan, D.B. et.all. (2015). Designing of Hydraulic Ram Pump. International Journal of Engineering and Computer Science 4(5), 1966-11971.

San, G.S. dan Santoso, G. (2003). Studi karakteristik volume tabung udara dan beban katup limbah terhadap efisiensi pompa Hydraulic Ram. Jurnal Teknik Mesin, $4(2), 81-87$.

Seth, J. ( 2013). How to build a Hydraulic Ram Pump. LandToHouse.com.

Sulistiawan, E., Wahyudi, R.T., Pradana, S., dan Fuhaid, N. (2013). Pengaruh volume tabung udara dan beban katub limbah terhadap efisiensi unjuk kerja pompa hidram. PROTON, 5(2), 1-4.

Young, B. W. (1996). Journal of Power and Energy, 210, 245-248. 